OPEN ACCESS

Edited by:

Elena V. Zaklyazminskaya,

Russian National Research Center of Surgery named after B.V.

Petrovsky, Russia

Reviewed by:

Viacheslav Nikolaev,

University of Göttingen, Germany

Luis. A Pardo,

Max Planck Institute for Experimental

Medicine, Germany

*Correspondence:

Aiqun Ma

maaiqun1108@126.com

Tingzhong Wang

tingzhong.wang@xjtu.edu.cn

tORCID:

Tingzhong Wang

orcid.org/0000-0002-6390-7967

Specialty section:

This article was submitted to Membrane Physiology

and Membrane Biophysics,

a section of the journal

Frontiers in Physiology

Received: 25 September 2020 Accepted: 12 November 2020 Published: 17 December 2020

Citation:

Dong C, Wang Y, Ma A and Wang T (2020) Life Cycle of the Cardiac Voltage-Gated Sodium

Channel Nav1.5.

Front. Physiol. 11:609733. doi: 10.3389/fphys.2020.609733

\section{Life Cycle of the Cardiac Voltage-Gated Sodium Channel Nav1.5}

\author{
Caijuan Dong' ${ }^{1}$, Ya Wang ${ }^{1}$, Aiqun Ma ${ }^{1,2,3 *}$ and Tingzhong Wang ${ }^{1,2,3 * t}$
}

${ }^{1}$ Department of Cardiovascular Medicine, First Affiliated Hospital of Xi'an Jiaotong University, Xi'an, China, ${ }^{2}$ Key Laboratory of Molecular Cardiology, Shaanxi Province, Xi'an, China, ${ }^{3}$ Key Laboratory of Environment and Genes Related to Diseases,

Xi'an Jiaotong University, Ministry of Education, Xi'an, China

Cardiac voltage-gated sodium channel Nav1.5, encoded by SCN5A, is crucial for the upstroke of action potential and excitation of cardiomyocytes. Nav1.5 undergoes complex processes before it reaches the target membrane microdomains and performs normal functions. A variety of protein partners are needed to achieve the balance between SCN5A transcription and mRNA decay, endoplasmic reticulum retention and export, Golgi apparatus retention and export, selective anchoring and degradation, activation, and inactivation of sodium currents. Subtle alterations can impair Nav1.5 in terms of expression or function, eventually leading to Nav1.5-associated diseases such as lethal arrhythmias and cardiomyopathy.

Keywords: Nav1.5, SCN5A, biosynthesis, trafficking, anchoring, degradation, gating modulation, posttranscriptional modification

\section{INTRODUCTION}

The cardiac voltage-gated sodium channel $\mathrm{Na}_{V} 1.5$ is made up of a $220-\mathrm{kDa}$ pore-forming $\alpha$-subunit and $30-\mathrm{kDa}$ auxiliary $\beta$-subunits. For the convenience of reading, $\mathrm{Na}_{V} 1.5$ in the following parts refers to the $\alpha$-subunit of $\mathrm{Na}_{\mathrm{V}} 1.5$. The SCN5A gene, found on chromosome $3 \mathrm{p} 21$, encodes the $\mathrm{Na}_{V} 1.5$ channel, which includes four homologous domains (DI-DIV), a C-terminus, and an N-terminus (Figure 1). Each domain of the $\mathrm{Na}_{\mathrm{V}} 1.5$ channel is composed of six membranespanning segments (S1-S6). Specifically, the S4 transmembrane segment acts as a voltage sensor. The S5 and S6 transmembrane segments form a pore with the intermembrane P-loop, which determines ion selectivity and influx (Jiang et al., 2020). The Nav 1.5 channel mediates the rapid influx of sodium ions $\left(\mathrm{Na}^{+}\right)$, which triggers cardiac action potential (AP), induces rapid depolarization, and initiates the excitation-contraction coupling cascades in the cardiomyocytes (Han et al., 2018). The sodium current $\left(I_{\mathrm{Na}}\right)$ generated by $\mathrm{Na}_{\mathrm{V}} 1.5$ is determined by the channel density on the plasma membrane and channel gating. $\mathrm{Na}_{V} 1.5$ is traditionally regarded as a monomer. However, it is well accepted that $\mathrm{Na}_{\mathrm{V}} 1.5$ is assembled as a dimer and exhibits coupled gating properties (Clatot et al., 2017). $\beta 1-\beta 4$ subunits, encoded by the SCN1b- $4 \mathrm{~b}$ genes, consist of an extracellular $\mathrm{N}$-terminus, a transmembrane $\alpha$-helix, and an intracellular $\mathrm{C}$ terminus (Salvage et al., 2020). The $\beta$-subunits act as gating modulators of $\mathrm{Na}_{V} 1.5$ and facilitate $\mathrm{Na}_{V} 1.5$ residence at the intercalated disk.

The life cycle of Nav 1.5 begins with the transcription of the SCN5A gene and RNA processing. Then, $\mathrm{Na}_{V} 1.5$ proteins are synthesized at the rough endoplasmic reticulum (ER) and follow the secretory pathway to reach the plasma membrane where the proteins exert their respective function. Various proteins are reported to be involved in the biosynthesis, trafficking, anchoring, 


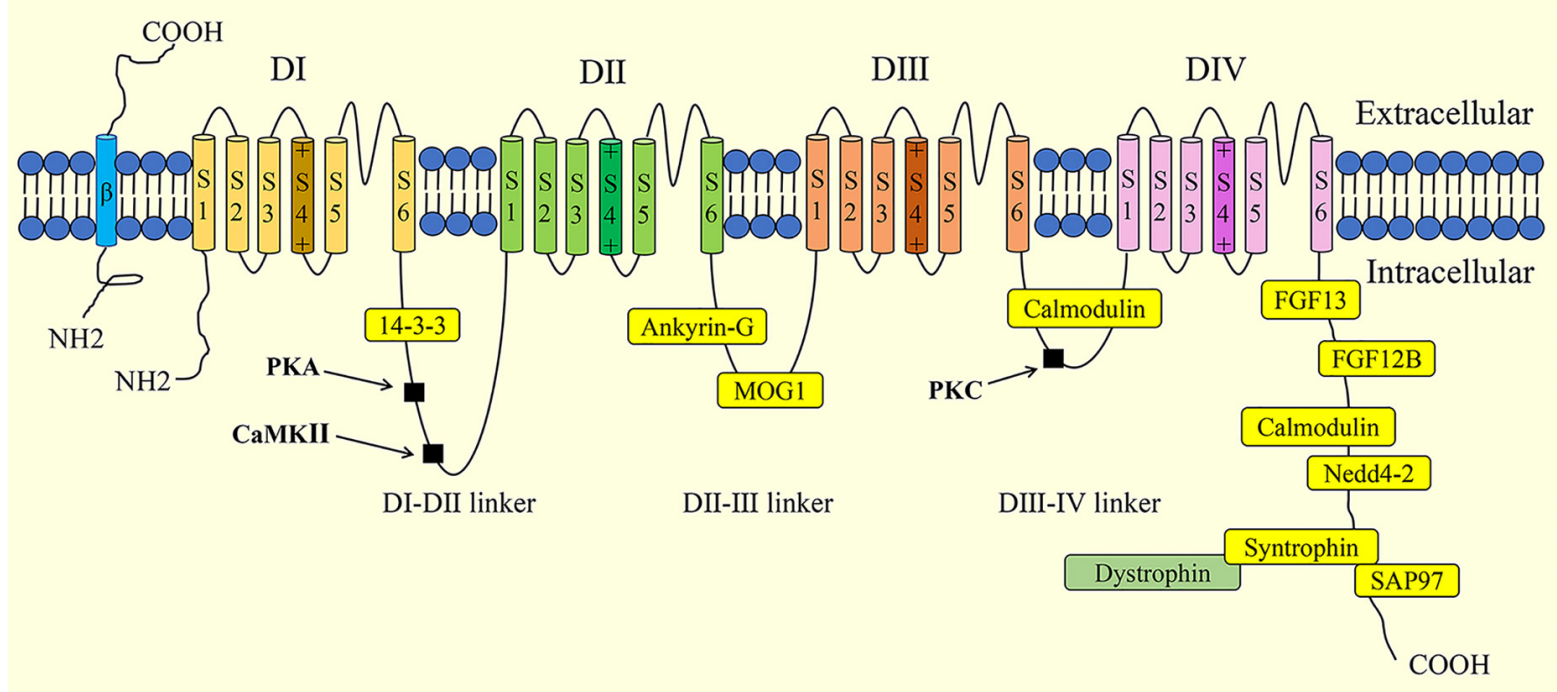

FIGURE 1 | Schematic illustration of the structure of cardiac sodium channel (Nav,1.5) and its interaction proteins. Phosphorylation sites are indicated in black squares. PKA, protein kinase A; CaMKII, $\mathrm{Ca}^{2+} /$ Calmodulin-dependent kinase II; PKC, protein kinase C; FGF, fibroblast growth factor; SAP97, synapse-associated protein 97.

post-transcriptional modification, gating regulation, and degradation of $\mathrm{Na}_{V} 1.5$ by directly or indirectly interacting with the different motifs and domains of $\mathrm{Na}_{V} 1.5$.

The aim of this review is to provide an updated account of the life cycle of $\mathrm{Na}_{V} 1.5$, while summarizing SCN5A-related diseases and novel therapeutic strategies targeting $\mathrm{Na}_{V} 1.5$.

\section{BIOSYNTHESIS}

Gene expression in eukaryotes starts with transcription, the transition of a DNA sequence into an RNA transcript (known as precursor mRNA) assisted with RNA polymerase and transcription factors. The precursor mRNA is the copying of the coding and noncoding genes which then need to undergo splicing and post-transcriptional modifications to produce mature mRNA and ultimately translate into polypeptides (Figure 2). The human SCN5A gene spans approximately $8,000 \mathrm{bp}$ and consists of 28 exons, which can be spliced together to generate the fulllength $\mathrm{Na}_{V} 1.5$ protein (about 2016 amino acids). Exons 228 encode the protein-coding sequence. Exon 1 and part of exon 2 encode the mRNA $5^{\prime}$-untranslated region (5'-UTR). Exon 28 encodes the mRNA 3'-UTR (Wang et al., 1996). The transcription of the $S C N 5 A$ gene is regulated by various transcription factors. Positive transcription factors such as TBX5 and NF- $\kappa$ B increase SCN5A mRNA abundance and further increase the expression and current of $\mathrm{Na}_{V} 1.5$, while negative transcription factors such as FOXO1 and Snail show the opposite effects (Table 1). MicroRNAs (miRNAs) regulate gene expression through translational repression or mRNA degradation. miR192-5p is reported to negatively regulate the expression of $\mathrm{Na}_{\mathrm{V}} 1.5$ and reduce $I_{\mathrm{Na}}$ density by interacting with the $3^{\prime}$-UTR of human SCN5A mRNA (Zhao et al., 2015).
Alternative splicing creates multiple variants of $\mathrm{Na}_{V} 1.5$ including functional and nonfunctional types (Schroeter et al., 2010). Compared to full-length $\mathrm{Na}_{V} 1.5$, spliced $\mathrm{Na}_{V} 1.5$ variants like $\mathrm{Na}$ 1.5a, $\mathrm{Na}$ 1.5d, and $\mathrm{Na}_{V} 1.5 \mathrm{e}$ present altered electrophysiological kinetic properties; $\mathrm{Na}_{\mathrm{V}} 1.5 \mathrm{c}$ show unchanged electrophysiological properties; $\mathrm{Na} v 1.5 \mathrm{~b}, \mathrm{Na}_{V} 1.5 \mathrm{f}$, and truncated variants E28B-E28D do not generate currents (Schroeter et al., 2010). The splicing machinery might explain the inconsistent genotype-phenotype outcomes. For instance, the LQT3-associated mutation SCN5A-T1620K showed electrophysiological properties similar to those of $h N a_{V} 1.5, h N a a_{V} 1.5 a$, and $h N a v 1.5 c$, but different effects in the hNa $1.5 d$ background (Gaetano et al., 2011). Nevertheless, the exact mechanisms of $\mathrm{Na}_{\mathrm{V}} 1.5$ splicing regulation are still unclear but involve species-dependent, tissue-specific, and developmental factors.

$\mathrm{Na}_{V} 1.5$ splice variants are reported to be involved in the pathophysiology of heart failure (HF), SCN5A channelopathies, and myotonic dystrophy. With angiotensin II (AngII) or hypoxia stimuli (signals common to HF), activated splice factors RBM25 and hLuc7A increase Nav1.5 splice variants E28C and E28D. Increased E28C and E28D variants cause a reading frame shift and encode truncated $\mathrm{Na}^{+}$channels before DIV of the channel due to premature stop codons (Gao et al., 2011). The nonfunctional channels are trapped in the endoplasmic reticulum (ER) and trigger the unfolded protein response (UPR). UPR activation further leads to destabilization of the remaining full-length SCN5A mRNA, exacerbating the reduction of $I_{\mathrm{Na}}$ (Gao et al., 2013; Noyes et al., 2017). Studies also found that SCN5A splicing in cardiomyocytes and white blood cell (WBC) changes in a correlated manner during HF. If altered WBCs SCN5A variants were proven to increase the risk of sudden death or other HF-associated arrhythmias, a blood examination 


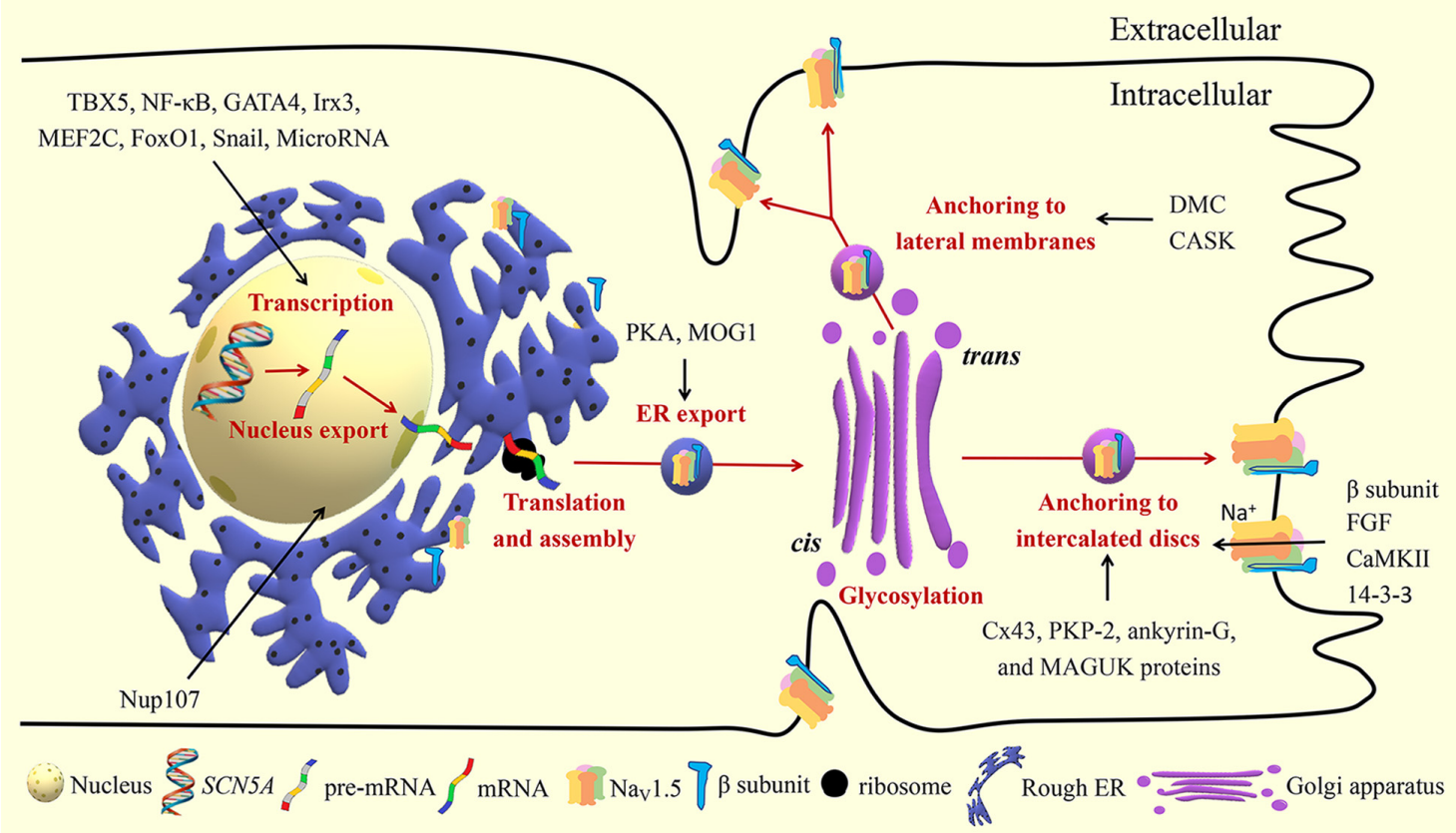

FIGURE 2 | Biosynthesis and trafficking of Nay 1.5. TBX5, T-box transcription factor 5; NF-kB, nuclear factor kappa-B; Irx3, Iroquois homeobox 3; MEF2C, myocyte enhancer factor-2C; Forkhead box 01; Nup107, nucleoporin 107; PKA, protein kinase A; Cx43, connexin 43; PKP-2, plakophilin 2; MAGUK, membrane-associated guanylate kinase; DMC, dystrophin-syntrophin multiprotein complex; CASK, calcium/calmodulin-dependent serine protein kinase; FGF, fibroblast growth factor; CaMKII, $\mathrm{Ca}^{2+}$ / calmodulin-dependent kinase II.

TABLE 1 | Transcription factors of Nav1.5 and their binding sites.

\begin{tabular}{|c|c|c|c|}
\hline \multicolumn{2}{|c|}{ Transcription Factors } & \multirow{2}{*}{$\begin{array}{l}\text { Binding Sites } \\
\text { an enhancer } \\
\text { downstream of the } \\
\text { SCN5A gene }\end{array}$} & \multirow{2}{*}{$\begin{array}{l}\text { Effects } \\
\text { The knockout of TBX5 from the mature murine ventricular conduction } \\
\text { system markedly decreases the density of Nav1.5, increases arrhythmias } \\
\text { propensity, and results in sudden cardiac death. }\end{array}$} \\
\hline Positive & TBX5 & & \\
\hline & $N F-\kappa B$ & $\begin{array}{l}\text { the } S C N 5 A \\
\text { promoter region }\end{array}$ & 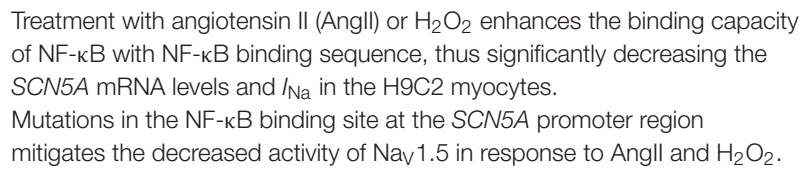 \\
\hline & GATA4/5 & $\begin{array}{l}\text { within the SCN5A } \\
\text { proximal promoter } \\
\text { and intron } 1 \text { regions }\end{array}$ & $\begin{array}{l}\text { GATA4 and GATA5 bind to the GATA binding site within the SCN5A } \\
\text { proximal promoter and intron } 1 \text { regions to synergistically activate the } \\
\text { SCN5A gene in the human left ventricle samples. } \\
\text { The GATA4 }{ }^{+/-} \text {heterozygous mice exhibited short PR intervals. }\end{array}$ \\
\hline & $\operatorname{IRX} 3$ & & $\begin{array}{l}\text { In the HL-1 cardiomyocytes and neonatal mouse ventricular myocytes, } \\
\text { overexpression of IRX3 upregulated the mRNA levels of SCN5A and CX40, } \\
\text { which was not observed by overexpressing mutant IRX3. } \\
\text { Deletion of IRX3 and IRX5 in the myocardium prolonged the atrioventricular } \\
\text { conduction, which is partly due to the activation of Nav1.5 expression }\end{array}$ \\
\hline & MEF2C & $\begin{array}{l}\text { within the } S C N 5 A \\
\text { promoter region }\end{array}$ & $\begin{array}{l}\text { Hu antigen } \mathrm{R}(\mathrm{HuR}) \text { increased the mRNA expression of MEF2C by inhibiting } \\
\text { MEF2C mRNA decay and consequently enhancing SCN5A mRNA } \\
\text { transcription. Consistently, these effects were attenuated upon transfecting } \\
\text { the cardiomyocytes with MEF2C siRNA. }\end{array}$ \\
\hline \multirow[t]{2}{*}{ Negative } & FOXO1 & & $\begin{array}{l}\text { FOXO1 negatively regulated Nav } 1.5 \text { expression by binding to the SCN5A } \\
\text { promoter and inhibiting its activity in the } \mathrm{HL}-1 \text { cardiomyocytes. } \\
\text { Deletion of FOXO1 increased the mRNA and protein levels of Nav } 1.5 \text { and } \\
\text { / }_{\mathrm{Na}} \text { in the ventricular myocytes. }\end{array}$ \\
\hline & Snail & $\begin{array}{l}\text { E-box sites in the } \\
\text { SCN5A core } \\
\text { promoter }\end{array}$ & $\begin{array}{l}\text { Overexpression of Snail in mice resulted in downregulated SCN5A mRNA } \\
\text { level, reduced Nav1.5 level and decreased } / \mathrm{Na} \text {. } \\
\text { CNS28 } /- \text { mice, which disrupted the Snail-binding region regulator, } \\
\text { exhibited significantly upregulated SCN5A mRNA level, increased Nav1.5 } \\
\text { level and enhanced } / \mathrm{Na} \text { in the freshly isolated ventricular myocytes. }\end{array}$ \\
\hline
\end{tabular}

\section{References}

Arnolds et al., 2012; Ivan et al., 2004; Steimle and Moskowitz, 2017

Shang and Dudley, 2005; Shang et al., 2008

Brewer and Pizzey, 2006; Munshi et al., 2009; Schluterman et al., 2003; Tarradas et al., 2017 Gaborit et al., 2012; Koizumi et al., 2016

Zhou et al., 2018a; Zhou et al., 2018b

Cai et al., 2014; Mao et al., 2012

Atack et al., 2011; Hesse et al., 2007; Nieto, 2002 
to predict HF-associated arrhythmic risk would be possible (Gao and Dudley, 2013).

\section{TRAFFICKING AND ANCHORING}

SCN5A mRNA exported from the nucleus is translated to protein and assembled in the rough ER. Next, the protein is translocated to the Golgi apparatus for further modification. After exiting the Golgi apparatus, Nav1.5 settles in the plasma membrane to exert its functions.

\section{Nucleus Export}

Nuclear pore complexes, also known as nucleoporins, mediate the exchange of molecules between the nucleoplasm and cytoplasm. Nucleoporin 107 (Nup107) selectively facilitates the export of SCN5A mRNA from the nucleus to cytoplasm without affecting the SCN5A mRNA level (Guan et al., 2019). Additionally, increased Nup107 and $\mathrm{Na}_{\mathrm{V}} 1.5$ were observed in the cardiomyocytes and heart tissues under hypoxic and oxidative stress conditions. This suggests that Nup107 is a protein that reacts rapidly to the insults and can be developed as a novel molecular therapeutic target for myocardial ischemic damage.

As of writing, it is not clear whether there are other nucleoporins that take part in the nucleus-cytoplasmic trafficking of SCN5A mRNA. MOG1 is found to interact with Ran GTP, a small protein that mediates the nucleus import and export of proteins and RNA (Steggerda and Paschal, 2001). MOG1 is shown to promote intracellular trafficking of $\mathrm{Na}_{\mathrm{V}} 1.5$ from the ER (Yu et al., 2018). Thus, MOG1 may also play a regulatory role in the nucleus-cytoplasmic trafficking of SCN5A mRNA.

\section{ER Export}

ER is the first station of the secretory pathway where the processes of protein folding, quality control, and protein complex assembly take place. Several ER retention and export motifs have been identified in ion channels (Mikosch and Homann, 2009; Benyair et al., 2011). ER export motifs are crucial for efficient ER export of mature and properly folded proteins through coat protein II (COPII) vesicles. COPII-coated vesicles in association with Sec23/24, Sec13/31, Sar1, and Sec12 mediate anterograde protein trafficking between the ER and Golgi (Kurokawa and Nakano, 2019). MOG1 facilitates the export of $\mathrm{Na}_{V} 1.5$ from the ER and improves $\mathrm{Na}_{V} 1.5$ expression on the cell surface, probably by interacting with Sar1 A and Sar1B (Chakrabarti et al., 2013; Wang et al., 2018; Yu et al., 2018; Kurokawa and Nakano, 2019). It is now recognized that ER retention signals can also play an important role in ER export of many plasma membrane proteins. After masking the ER retention signals, the proteins seem to receive an "exit card" and are released from the ER. The DIII linker region of $\mathrm{Na}_{V} 1.5$ contains three putative RXR-type ER retention motifs (479RKR481, 533RRR535, and 659RQR661). Protein kinase A (PKA)-mediated phosphorylation of $\mathrm{Na}_{V} 1.5$ masks the retention signals in the DI-II linker region of $\mathrm{Na}_{\mathrm{V}} 1.5$, and promotes the export of $\mathrm{Na}_{V} 1.5$ from the ER to the Golgi (Zhou et al., 2002; Rook et al., 2012).
Nevertheless, the ER export mechanism of $\mathrm{Na}_{V} 1.5$ is still poorly understood. Rab GTPases, the largest members of the Ras superfamily, play an important role in protein trafficking between intracellular compartments in eukaryotes (Li and Marlin, 2018). Rab1 and Rab2 are reported to regulate protein transport between the ER and Golgi, but their role in $\mathrm{Na}_{\mathrm{V}} 1.5$ trafficking is uncertain and needs to be tested in further studies.

\section{Golgi Export}

Selective Golgi export of proteins from the Golgi to the plasma membrane is another key step in protein trafficking, which has been studied in inward-rectifying potassium channels (Li et al., 2016). However, little is known about the regulation of $\mathrm{Na}_{V} 1.5$ transport from the Golgi. It is speculated that Golgi retention and export motifs possibly modulate $\mathrm{Na}_{\mathrm{V}} 1.5$ exit from the Golgi (Gao et al., 2014).

\section{Anchoring}

Cardiac $\mathrm{Na}_{\mathrm{V}} 1.5$ channels are arranged in clusters, also called pools, in the following membrane microdomains of cardiomyocytes: intercalated discs (ID), T-tubules, costameres, and caveolae. ID mainly consist of three intercellular adhesion structures namely, gap junctions, adherens junctions, and desmosomes (Clark et al., 2002). ID is responsible for electromechanical coupling. The upstroke of AP caused by $\mathrm{Na}^{+}$influx through $\mathrm{Na}_{\mathrm{V}} 1.5$ channels can spread quickly through IDs to ensure the coordinated excitation and contraction among cardiomyocytes. T-tubules are tubular invaginations of the lateral sarcolemma that link the sarcoplasmic reticulum and initiate excitation-contraction coupling. AP mediated by $\mathrm{Na}_{V} 1.5$ is transmitted along the T-tubules, induces calcium release, and further triggers the contraction of cardiomyocytes. Costameres are sarcolemmal transverse rib-like structures that adhere adjacent cardiomyocytes to the extracellular matrix and maintain the three-dimensional structure of the myocardium (Balse and Eichel, 2018). Caveolae are $50-100 \mathrm{~nm}$ cave-like invaginations of the plasma membrane that are made up of essential scaffolding proteins called caveolins. Besides sodium channels $\left(\mathrm{Na}_{V} 1.5\right)$, L-type calcium channels, potassium channels $\left(\mathrm{K}_{\mathrm{V}} 1.5\right)$, sodiumcalcium exchanger, and $\mathrm{Na}^{+} / \mathrm{K}^{+}$ATPase have been subcellularly localized to caveolae and may allow these channels to be integrated into macromolecular complexes to exert their functions and to be regulated in a unified manner (Balijepalli and Kamp, 2008). T-tubules, costameres, and caveolae are all located in the lateral membranes of cardiomyocytes. Nav 1.5 channels are located in different membrane microdomains of cardiomyocytes, which are determined by their specific partners, such as cytoskeleton-binding proteins, gap junctional proteins, and desmosomal proteins (Table 2; Balse and Eichel, 2018).

To our knowledge, a sorting process at the early stages possibly exists, which affects the final anchoring of membrane proteins toward specific microdomains. To better understand the mechanism of $\mathrm{Na}_{V} 1.5$ anchoring, it is of great value to investigate the complex processes of sorting, identification by protein chaperones, and organization of microdomains, both in physiological and pathological conditions. 
TABLE 2 | Protein partners associated with $\mathrm{Na}_{\mathrm{v}} 1.5$ localization in the cardiomyocytes.

\begin{tabular}{|c|c|c|c|}
\hline Classification & Representation & Localization & References \\
\hline $\begin{array}{l}\text { Cytoskeleton- } \\
\text { binding } \\
\text { proteins }\end{array}$ & ankyrin-G & intercalated disks & $\begin{array}{l}\text { Makara et al., 2014; } \\
\text { Yang et al., } 2020\end{array}$ \\
\hline \multirow[t]{2}{*}{$\begin{array}{l}\text { Gap junctional } \\
\text { proteins }\end{array}$} & Connexin 43 & intercalated disks & $\begin{array}{l}\text { Bruce et al., 2008; } \\
\text { Sottas et al., } 2018\end{array}$ \\
\hline & Plakophilin 2 & intercalated disks & Sato et al., 2009 \\
\hline $\begin{array}{l}\text { Desmosomal } \\
\text { proteins }\end{array}$ & $\begin{array}{l}\text { Desmoglein } 2 \\
\text { Desmoplakin }\end{array}$ & $\begin{array}{l}\text { intercalated disks } \\
\text { intercalated disks }\end{array}$ & $\begin{array}{l}\text { Rizzo et al., } 2012 \\
\text { Zhang et al., } 2013\end{array}$ \\
\hline $\begin{array}{l}\text { Dystrophin- } \\
\text { syntrophin } \\
\text { complex }\end{array}$ & Dystrophin & lateral membranes & Gavillet et al., 2006 \\
\hline Caveolins & Caveolin-3 & Caveolae & $\begin{array}{l}\text { Cheng et al., 2013; } \\
\text { Gavillet et al., 2006; } \\
\text { Schilling et al., 2016; } \\
\text { Vaidyanathan et al., } \\
2018\end{array}$ \\
\hline MAGUK & SAP97 & intercalated disks & Petitprez et al., 2011 \\
\hline proteins & CASK & lateral membranes & Eichel et al., 2016 \\
\hline
\end{tabular}

\section{DEGRADATION}

The last step of the Nav1.5 channel life cycle is degradation, which can be considered as a form of retrograde trafficking (Figure 3). There are two major pathways for the degradation of Nav 1.5: the proteasome and autophagic degradation pathways.

\section{Proteasome Degradation Pathway}

Ubiquitination is a common signal for protein internalization and degradation. E3 ubiquitin ligase Nedd4-2 contains WW domains, an N-terminal calcium/protein binding C2 domain, and a C-terminal HECT domain. When the $\mathrm{C} 2$ domain binds to the HECT domain, Nedd4-2 presents an inactive state. When $\mathrm{Ca}^{2+}$ binds to the $\mathrm{C} 2$ domain, the HECT domain is exposed and Nedd4-2 is activated. Activated Nedd4-2 binds to the PY motifs of target proteins through its WW domains for ubiquitination (Lamothe and Zhang, 2016). Ion channels tagged with ubiquitin are usually compartmentalized into vesicles destined for degradation (by the lysosomal or proteasomal system) or recycled back to the membrane via small GTPase Rabs. Nedd4-2 binds to the PY motif of Nav 1.5 through WW domains for ubiquitination, which leads to the rapid internalization and degradation of $\mathrm{Na}_{V} 1.5$ (van Bemmelen et al., 2004). Calciumdependent Nedd4-2 upregulation accelerates the degradation of $\mathrm{Na}_{V} 1.5$ and decreases the $I_{\mathrm{Nac}}$ density on the plasma membrane (Luo et al., 2017). $\alpha$ B-crystallin (Huang et al., 2016), serum- and glucocorticoid-inducible kinase (SGK) (Boehmer et al., 2003), and UBC9 (Tang et al., 2019) are reported to interact with Nedd4-2 to regulate the degradation of $\mathrm{Na}_{\mathrm{V}} 1.5$.

\section{Autophagic Degradation Pathway}

Adenosine $5^{\prime}$-monophosphate-activated protein kinase (AMPK) plays a major role in mediating the autophagic degradation of $\mathrm{Na}_{V} 1.5$ during cardiac ischemia and reperfusion (I/R) injury. I/R stimulation was reported to downregulate $\mathrm{Nav} 1.5$ abundance in rat hearts. An in vitro study showed that under conditions of I/R stress, Nav1.5 was degraded through the AMPK-mediated autophagic pathway rather than through the proteasome pathway (Tang et al., 2019). AMPK assists Nav1.5 to bind to the autophagic adapter protein and microtubule-associated protein 1 light chain 3 (LC3) by phosphorylating $\mathrm{Na}_{\mathrm{V}} 1.5$ at threonine (T) 101, and enhances the subsequent degradation through the autophagic pathway (Liu et al., 2019).

\section{MODULATION OF THE GATING PROPERTIES}

$\mathrm{Na}_{V} 1.5$ activation depends on the S4 segment, which contains multiple positively charged amino acids that move across the membrane in response to changes in membrane potential. The voltage-sensing domain (VSD), formed by S1-S4, rotates when membrane depolarization moves the S4 segment within DIDIII outward relative to other channel segments. This allows $\mathrm{Na}^{+}$to flow inwardly through the pores composed of the $\mathrm{S} 5$ and S6 segments and the P loop. Early $I_{\mathrm{Na}}$ induces rapid AP upstroke, leading to further channel activation. Nav1.5 inactivation involves two distinct processes: fast and slow inactivation. Fast inactivation is coupled to the activation process and occurs within milliseconds. This process may involve an isoleucine-phenylalanine methionine (IFM) motif, which is a highly conserved amino acid triplet in the III-IV linker (Chadda et al., 2017). Unlike fast inactivation, slow inactivation is not coupled to the activation process and can last for as long as a few seconds. Conformational modifications in the following three domains drive the slow inactivation process: the trans-membrane segment S4/D4, the loop between S5-S6/DII (P-loop/DII), and segment S6/DII (Detta et al., 2015).When Na 1.5 channels do not completely inactivate, a lasting current less than $0.5 \%$ of the peak current can be detected in the cardiomyocytes, which is known as late $I_{\mathrm{Na}}\left(I_{\mathrm{Na}-\mathrm{L}}\right)$. Because of the short duration of the AP plateau, $I_{\mathrm{Na}-\mathrm{L}}$ can result in situations where the $\mathrm{Na}^{+}$"load" becomes twice as much as peak $I_{\mathrm{Na}-\mathrm{P}}$ over time, and this plays an important role in angina, arrhythmia, and HF (Makielski, 2016). Many proteins have been identified to modulate the gating properties of $\mathrm{Na}_{V} 1.5$, such as $\beta$-subunits, FGF, CaMKII, and 14-3-3. Their interacting domains and modulation effects are summarized in Table 3.

\section{POST-TRANSCRIPTIONAL MODIFICATIONS}

Interacting proteins modify the structure and properties of $\mathrm{Na}_{V} 1.5$ through post-transcriptional modifications (PTMs), such as glycosylation, phosphorylation, methylation, acetylation, and ubiquitylation. PTMs, such as PKA- and CaMKII-mediated phosphorylation and Nedd4-2-mediated ubiquitylation have been discussed in the former sections. We will put more emphasis on the glycosylation, SUMOylation,methylation, and acetylation of $\mathrm{Na}_{\mathrm{V}} 1.5$ in the following sections. 


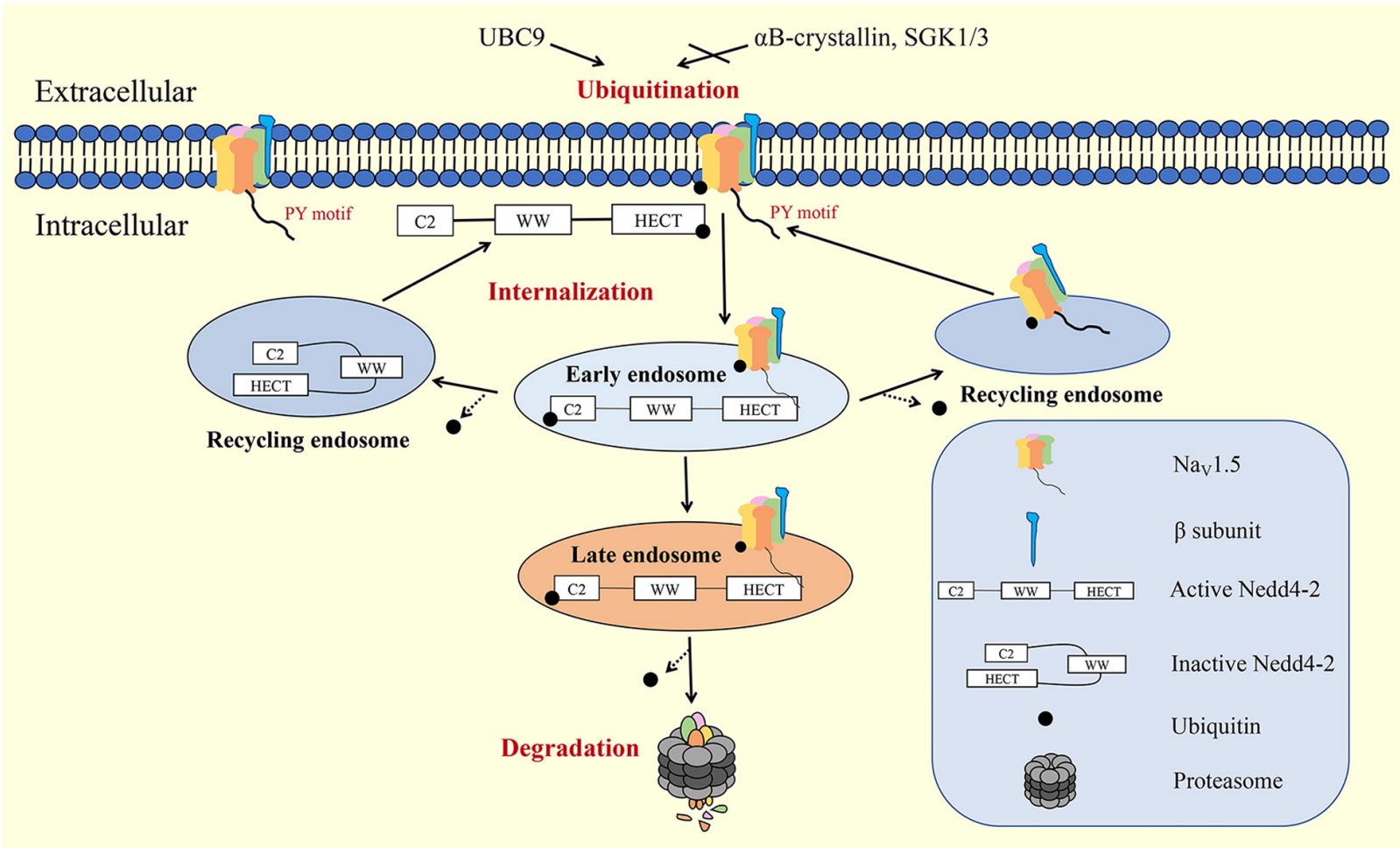

FIGURE 3 | Internalization and degradation of Nav1.5 on the plasma membrane. Nedd4-2, neural precursor cell-expressed developmentally downregulated 4 type 2; SGK, serum- and glucocorticoid-inducible kinase.

\section{Glycosylation}

Many ion channels are known to contain glycan moieties oriented toward the outside of the membrane, which are anchored to residues, such as serine, threonine (O-linked glycosylation), or asparagine (N-linked glycosylation) (Marionneau and Abriel, 2015). Sialic acids, which are negatively charged terminal residues, are subsequently linked with $\mathrm{N}$-glycans or O-glycans through trans-Golgi sialyltransferase activity and contribute to the extracellular surface potential. The $\mathrm{Na}_{\mathrm{V}}$ is a heavily $\mathrm{N}$-glycosylated protein with carbohydrates that make up 20 to $30 \%$ of total mass. However, $\mathrm{Na}_{\mathrm{V}} 1.5$ is an exception, with approximately $5 \%$ by weight of carbohydrates (Mercier et al., 2015). N-glycosylation, which is initiated in the ER and terminated in the Golgi apparatus, is reported to be essential for membrane localization and gating properties. The D25N mutation of the $\beta 1$ subunit resulted in decreased targeting of $\mathrm{Na}_{\mathrm{V}} 1.5$ to the plasma membrane due to a maturation (glycosylation) defect (Baroni et al., 2018). Ventricular $\mathrm{Na}_{V}$ from ST3Gal4 (a glycogene responsible for glycoprotein sialylation) deficient mice is reported to exhibit gating at higher depolarized potentials, slower inactivation, and faster recovery than in control mice (Ednie et al., 2013).

\section{Methylation}

Arginine methylation within the interdomain linker between DI and DII of $\mathrm{Na}_{\mathrm{V}} 1.5$ is catalyzed by protein arginine methyltransferases (PRMT), which transfer methyl groups from the cofactor S-adenosyl-L-methionine (SAM) to the protein. Arginine methylation is an important PTM in voltage-gated ion channels. PRMT-3 and -5 methylate $\mathrm{Na}_{V} 1.5$ and increase $\mathrm{Na}_{V} 1.5$ current density by increasing the cell surface expression in HEK293 cells (Beltran-Alvarez et al., 2013). Arginine methylation of $\mathrm{Na}_{V} 1.5$ is also detected in the human heart tissue of patients with end-stage HF. Additionally, R526 methylation is identified as the major $\mathrm{Na}_{V} 1.5$ methylation site in patients with end-stage HF (Beltran-Alvarez et al., 2014). Moreover, the methylation-phosphorylation crosstalk of $\mathrm{Na}_{\mathrm{V}} 1.5$ has been previously reported. $\mathrm{Na}_{\mathrm{V}} 1.5$ methylation at R513 significantly decreased S516 phosphorylation, which consequently hindered R513 methylation (Beltran-Alvarez et al., 2015).

\section{Acetylation}

$\mathrm{N}$-terminal acetylation, which is irreversibly catalyzed by ribosome-associated N-terminal acetyltransferases (NATs), is a major PTM of eukaryotic proteins that regulates protein-protein interactions and membrane targeting. Recently, N-terminal acetylation has been reported to be a degradation signal that inhibits protein targeting to the secretory pathway (Arnesen, 2011). N-terminal acetylation of $\mathrm{Na}_{V} 1.5$ at the initial 30 alanine residues was discovered in the hearts of patients with endstage HF (Beltran-Alvarez et al., 2014). In contrast, N-lysine acetylation, which is catalyzed by histone acetyltransferases (HATs), can be reversed by histone deacetylases and sirtuins. Sirtuin1 deacetylase-mediated acetylation at lysine 1479 of 
TABLE 3 | Proteins and their modulation effects on the gating properties of Nav1.5 channels.

\begin{tabular}{|c|c|c|c|c|}
\hline Proteins & & $\begin{array}{l}\text { Interacting } \\
\text { domains }\end{array}$ & Modulation effects of gating properties & References \\
\hline \multirow[t]{4}{*}{$\beta$-subunits } & $\beta 1$ & DIV-VSD & $\begin{array}{l}\text { Co-expression of } \beta 1 \text { with cardiac } \mathrm{Na}_{\mathrm{V}} 1.5 \mathrm{in} \text { Xenopus oocytes increased } / \mathrm{Na} \\
\text { amplitude, resulting in a depolarizing shift in steady-state inactivation and enhances } \\
\text { recovery from inactivation. } \\
\text { Overexpressing } \beta 1 \text { caused significant hyperpolarizing shifts in both activation and } \\
\text { inactivation kinetics, and greatly reduced persistent } / \mathrm{Na}-\mathrm{L} \text { in the Chinese hamster } \\
\text { ovary cells stably expressing human } \mathrm{Nav} 1.5 \text {. }\end{array}$ & $\begin{array}{l}\text { Fahmi et al., 2001; Ko } \\
\text { et al., 2005; Zhu et al., } \\
2017\end{array}$ \\
\hline & $\beta 2$ & & $\begin{array}{l}\text { Co-expression of } \beta 2 \text { with Nav } 1.5 \text { caused a negative shift in activation in Pro5 and } \\
\text { Lec } 2 \text { cells. } \\
\text { Co-expression of } \beta 2 \text { with Nav } 1.5 \text { caused a positive shift in inactivation in Chinese } \\
\text { hamster ovary cells. }\end{array}$ & $\begin{array}{l}\text { Johnson and Bennett, } \\
\text { 2006; Watanabe et al., } \\
2009\end{array}$ \\
\hline & $\beta 3$ & DIII-VSD & $\begin{array}{l}\text { Overexpressing } \beta 3 \text { accelerated macroscopic current decay, caused hyperpolarizing } \\
\text { shifts in both activation and inactivation kinetics, slowed recovery from inactivation, } \\
\text { and greatly reduced persistent / } \mathrm{Na}-\mathrm{L} \text { in the Chinese hamster ovary cells stably } \\
\text { expressing human Nav1.5. }\end{array}$ & $\begin{array}{l}\text { Ko et al., 2005; Zhu } \\
\text { et al., } 2017\end{array}$ \\
\hline & $\beta 4$ & & $\begin{array}{l}\text { Controversial. } \\
\text { Medeiros-Domingo's study showed that overexpression of } \beta 4 \text { with Nav1.5 } \\
\text { significantly increased the slope factors of both activation and inactivation, shifted } \\
\text { the inactivation curve to a more negative potential, and reduced slow recovery from } \\
\text { inactivation in HEK293 cells stably expressing Nav1.5. Tan's study showed that } \\
\text { co-expression of } \beta 4 \text { with Nav1.5 did not affect the activation or recovery from } \\
\text { inactivation of the cardiac sodium current, but significantly shifted the inactivation } \\
\text { curve to a more negative potential in HEK293 cells. However, in Qin Yang's study, } \\
\text { they did not observe any significant effect. }\end{array}$ & $\begin{array}{l}\text { Medeiros-Domingo } \\
\text { et al., 2007; Tan et al., } \\
\text { 2010; Yang et al., } 2019\end{array}$ \\
\hline \multirow[t]{2}{*}{ FGF } & FGF12 & C-terminus & $\begin{array}{l}\text { Overexpression of FGF12 exhibited a significant hyperpolarizing shift in } \\
\text { voltage-dependent inactivation without affecting the activation of } \mathrm{Nav}_{1} 1.5 \text {. }\end{array}$ & Liu et al., 2003 \\
\hline & FGF13 & C-terminus & $\begin{array}{l}\text { The knockout of FGF13 in adult mouse ventricular myocytes delayed recovery from } \\
\text { inactivation of Nav1.5. }\end{array}$ & Wang et al., 2011 \\
\hline CaMKII & & IQ motif & $\begin{array}{l}\text { Overexpressing CaMKII exhibited a depolarizing shift in sodium channel inactivation } \\
\text { and increased / } \mathrm{Na}-\mathrm{L} \text { in rabbit, mouse and the guinea pig ventricular } \\
\text { cardiomyocytes. Its effects on recovery from inactivation and intermediate or slow } \\
\text { inactivation of Nav1.5 are controversial. }\end{array}$ & $\begin{array}{l}\text { Aiba et al., 2010; } \\
\text { Wagner et al., } 2006\end{array}$ \\
\hline $14-3-3 \eta$ & & $\begin{array}{l}\text { the first interdomain } \\
\text { of Nav } 1.5 \\
\text { between amino } \\
\text { acids } 417 \text { and } 467\end{array}$ & $\begin{array}{l}\text { The co-expression of } \mathrm{Nav} 1.5, \beta 1 \text { subunit and } 14-3-3 \eta \text { in the COS- } 7 \text { cells resulted in } \\
\text { a negative shift in inactivation and a delayed recovery from inactivation without } \\
\text { changes in the activation and current density. } \\
14-3-3 \eta \text { mediated coupled gating. }\end{array}$ & $\begin{array}{l}\text { Allouis et al., 2006; } \\
\text { Clatot et al., } 2017\end{array}$ \\
\hline
\end{tabular}

$\mathrm{Na}_{\mathrm{V}} 1.5$ results in enhanced trafficking to the surface of the plasma membrane and increased $I_{\mathrm{Na}}$ (Yoon et al., 2017).

\section{SUMOylation}

SUMOylation, a PTM, is analogous to ubiquitylation involving an enzymatic cascade. In contrast to ubiquitylation, SUMOylation involves conjugating the proteins to small ubiquitin-like modifiers (SUMOs). SUMOylation can affect protein structure and subcellular localization. Recently, $\mathrm{Na}_{V} 1.5$ was reported to be SUMOylated only at lysine 442 . The mutation of lysine 442 or application of a deSUMOylating enzyme inhibits hypoxic reopening in response to hypoxia. SUMOylation of $\mathrm{Na}_{V} 1.5$ is associated with an increase in $I_{\mathrm{Na}-\mathrm{L}}$ (Plant et al., 2020).

Recently, novel post-transcriptional modifications have been reported. Zhang et al. found that an endogenous "lactate clock" turns on gene expression to promote homeostasis in bacterially challenged M1 macrophages (Zhang et al., 2019). The presence of histone lactylation represents a new avenue for understanding the pathophysiological mechanism of many diseases, including ischemic cardiovascular disease. It has been established that Nav 1.5 channels are significantly downregulated under conditions of ischemia and hypoxia, which is accompanied by the accumulation of lactic acid. Whether lactylation is involved in the regulation of $\mathrm{Na}_{\mathrm{V}} 1.5$ under pathological conditions has not yet been revealed.

\section{SCN5A-RELATED DISEASES AND POTENTIAL THERAPY STRATEGY}

$\mathrm{Na}_{V} 1.5$ is associated with the pathogenesis of various cardiovascular diseases, such as arrhythmia, ischemic cardiomyopathy, heart failure, and sudden cardiac death. Most cases of cardiac arrhythmia and sudden cardiac death are caused by $S C N 5 A$-related mutations, which change $\mathrm{Na}_{V} 1.5$ expression and function. The gain-of-function mutations in $S C N 5 A$, which lead to increased $I_{\mathrm{Na}-\mathrm{L}}$, can lead to long QT syndrome 3 (LQT3). Loss-of-function mutations in SCN5A, which lead to decreased $I_{\mathrm{Na}}$, can cause Brugada syndrome (BrS), sick sinus node syndrome, and atrial fibrillation (Li et al., 2018). To date, the reported BrS-associated SCN5A mutations and LQT3-associated mutations are over 300 and over 80, 
respectively. Previous studies have demonstrated that $\mathrm{Na}_{V} 1.5$ expression is downregulated in HF (Luo et al., 2017). The upregulated expression of Nedd4-2, co-localization of Nedd4-2 with $\mathrm{Na}_{V} 1.5$, and increased diastolic calcium concentrations were observed in the volume-overloaded HF rat model, suggesting that Nedd4-2-mediated ubiquitination plays an important role in the downregulation of $\mathrm{Na}_{\mathrm{V}} 1.5$ in HF (Luo et al., 2017). SCN5A variants are now recognized to be involved in the pathogenesis of HF. A1180V, an SCN5A variant, decreased $I_{\mathrm{Na}}$ and moderately increased $I_{\mathrm{Na}-\mathrm{L}}$. A $1180 \mathrm{~V}$ carriers without cardiac dysfunction initially exhibit deteriorated cardiac functions and progress to HF or atrioventricular block during follow-up (Ge et al., 2008). Although some studies have elucidated the correlation between $\mathrm{Na}_{\mathrm{V}} 1.5$ and HF, the specific mechanisms are not yet known.

Considering the important role of $\mathrm{Na}_{\mathrm{V}} 1.5$ in these diseases, novel therapeutic strategies targeting the biosynthesis, trafficking, and sodium current of $\mathrm{Na}_{\mathrm{V}} 1.5$ have been developed.

\section{Treatment Targeting Biosynthesis of Nav1.5}

Several studies have proposed that promoting the process of translational readthrough can enable ribosomes to neglect the stop codon to produce full-length proteins and reduce the harmful results caused by nonsense mutations to a certain degree. Pharmacological strategies to enhance translational readthrough include aminoglycosides, small-interfering RNA (siRNA) that target eukaryotic release factors (eRF), and suppressor tRNAs that recognize stop codons (Carnes et al., 2003). This idea was tested in the nonsense mutation SCN5A-W822X by using aminoglycosides and siRNA against eRF3a and proved effective, which might be a novel treatment strategy for nonsense SCN5A mutation carriers (Teng et al., 2009). However, its application in clinical practice is largely limited due to safety concerns, such as introducing sequence changes to restored full-length proteins.

\section{Treatment Targeting Trafficking of $\mathrm{Na}_{\mathrm{v}} \mathbf{1 . 5}$}

H558R, a common SCN5A polymorphism, restores the defective trafficking of BrS-associated SCN5A mutations R282H, S216L, $\mathrm{K} 317 \mathrm{~N}$, and D1690N by promoting proper protein folding (Marangoni et al., 2011; Shinlapawittayatorn et al., 2011; Nunez et al., 2013). The mechanisms by which H558R rescues $S C N 5 A$ mutations are controversial. Decreased SCN5A promoter methylation by $\mathrm{H} 588 \mathrm{R}$ is one of the mechanisms involved (Matsumura et al., 2017). In an in vitro study, small peptides that span the H558R polymorphism, have been shown to be sufficient in restoring the trafficking defect of BrS-associated SCN5A mutations-R282H, indicating that it might be possible to use R558-containing peptides as a novel strategy tailored to specific BrS mutants (Shinlapawittayatorn et al., 2011). However, the rescue effects in vivo still need to be investigated.

\section{Treatment Targeting $I_{\mathrm{Na}-\mathrm{L}}$ of $\mathrm{Nav} 1.5$}

Ranolazine, eleclazine, amiodarone, mexiletine, flecainide, and quinidine targeting $I_{\mathrm{Na}-\mathrm{L}}$ have been widely studied for the treatment of LQT3 patients (Makielski, 2016). For example, we take mexiletine and ranolazine. Ranolazine, which is approved for the treatment of angina pectoris, preferentially reduces $I_{\mathrm{Na}-\mathrm{L}}$. To date, Ranolazine has been investigated with respect to SCN5A mutations such as $\triangle \mathrm{KPQ}, \mathrm{Y} 1767 \mathrm{C}, \mathrm{R} 1623 \mathrm{Q}$, and D1790G (Moss et al., 2008; Rajamani et al., 2009; Huang et al., 2011; Chorin et al., 2016). Mexiletine, an oral class Ib anti-arrhythmic agent, targets cardiac $\mathrm{Na}_{\mathrm{V}} 1.5$, and preferentially inhibits $I_{\mathrm{Na}-\mathrm{L}}$. It has been reported that mexiletine can effectively shorten the QT interval in a subset of patients with LQT3, while other patients are insensitive to the drug (Mazzanti et al., 2016). The conformation of the less activated DIII voltage-sensing domain (DIII-VSD) of $\mathrm{Na}_{V} 1.5$ is hypothesized to be the cause for mexiletine insensitivity in these patients (Zhu et al., 2019). A combination of mexiletine with a drug that can promote DIII-VSD activation can be a novel therapeutic strategy for these mexiletine-insensitive patients.

\section{CONCLUSION AND PERSPECTIVES}

The life cycle of $\mathrm{Na}_{\mathrm{V}} 1.5$ begins with the transcription and translation of the SCN5A gene. Nav 1.5 is then trafficked from the ER to the Golgi apparatus and subsequently to the sarcolemma and cytoskeleton. Finally, $\mathrm{Na}_{\mathrm{V}} 1.5$ is internalized and degraded. In the past decades, great achievements have been made in the regulation of $\mathrm{Na}_{\mathrm{V}} 1.5$ from biosynthesis and trafficking to degradation. The knowledge we have generated helps in the understanding of the pathogenesis of SCN5A-related diseases and management of these patients. However, the complete life cycle of $\mathrm{Na}_{\mathrm{V}} 1.5$ has not been fully mapped. In the end of each section, we have pointed out the corresponding unsolved problems. All these problems can be summarized in two sections: regulation of $\mathrm{Na}_{\mathrm{V}} 1.5$ under physiological conditions and in pathological conditions. We believe that with joint efforts, we will achieve a deeper understanding of the life cycle of $\mathrm{Na}_{V} 1.5$ and explore more effective treatment strategies to reduce mortality and improve the quality of life of patients suffering from SCN5A-related diseases.

\section{AUTHOR CONTRIBUTIONS}

CD and YW drafted the manuscript. AM and TW conceived and supervised the review. All authors contributed to the article and approved the submitted version.

\section{FUNDING}

This project was supported by the National Natural Science Foundation of China (81870256 to TW and 81600272 to AM) and the Key Program of International Cooperation and Exchanges of Shaanxi, China (2018KW-061 to TW).

\section{ACKNOWLEDGMENTS}

We thank the highly qualified native English-speaking editors at Wiley Editing Services for editing the English. 


\section{REFERENCES}

Aiba, T., Hesketh, G. G., Liu, T., Carlisle, R., Villa-Abrille, M. C., O’Rourke, B., et al. (2010). $\mathrm{Na}+$ channel regulation by $\mathrm{Ca} 2+/$ calmodulin and $\mathrm{Ca} 2+$ /calmodulindependent protein kinase II in guinea-pig ventricular myocytes. Cardiovasc. Res. 85, 454-463. doi: 10.1093/cvr/cvp324

Allouis, M., Le Bouffant, F., Wilders, R., Peroz, D., Schott, J. J., Noireaud, J., et al. (2006). 14-3-3 Is a regulator of the cardiac voltage-gated sodium channel Nav 1.5. Circ. Res. 98, 1538-1546. doi: 10.1161/01.RES.0000229244.97497.2c

Arnesen, T. (2011). Towards a functional understanding of protein N-terminal acetylation. PLoS Biol. 9:e1001074. doi: 10.1371/journal.pbio.1001074

Arnolds, D. E., Liu, F., Fahrenbach, J. P., Kim, G. H., Schillinger, K. J., Smemo, S., et al. (2012). TBX5 drives SCN5A expression to regulate cardiac conduction system function. J. Clin. Invest. 122, 2509-2518. doi: 10.1172/JCI62617

Atack, T. C., Stroud, D. M., Watanabe, H., Yang, T., Hall, L., Hipkens, S. B., et al. (2011). Informatic and functional approaches to identifying a regulatory region for the cardiac sodium channel. Circ. Res. 109, 38-46. doi: 10.1161/ CIRCRESAHA.110.235630

Balijepalli, R. C., and Kamp, T. J. (2008). Caveolae, ion channels and cardiac arrhythmias. Prog. Biophys. Mol. Biol. 98, 149-160. doi: 10.1016/j.pbiomolbio. 2009.01.012

Balse, E., and Eichel, C. (2018). The cardiac sodium channel and its protein partners. Handb. Exp. Pharmacol. 246, 73-99. doi: 10.1007/164_2017_45

Baroni, D., Picco, C., and Moran, O. (2018). A mutation ofSCN1B associated with GEFS + causes functional and maturation defects of the voltage-dependent sodium channel. Hum. Mutat. 39, 1402-1415. doi: 10.1002/humu.23589

Beltran-Alvarez, P., Espejo, A., Schmauder, R., Beltran, C., Mrowka, R., Linke, T., et al. (2013). Protein arginine methyl transferases- 3 and -5 increase cell surface expression of cardiac sodium channel. FEBS Lett. 587, 3159-3165. doi: 10.1016/j.febslet.2013.07.043

Beltran-Alvarez, P., Feixas, F., Osuna, S., Díaz-Hernández, R., Brugada, R., and Pagans, S. (2015). Interplay between R513 methylation and S516 phosphorylation of the cardiac voltage-gated sodium channel. Amino Acids 472, 429-434. doi: 10.1007/s00726-014-1890-0

Beltran-Alvarez, P., Tarradas, A., Chiva, C., Perez-Serra, A., Batlle, M., Perez-Villa, F., et al. (2014). Identification of $\mathrm{N}$-terminal protein acetylation and arginine methylation of the voltage-gated sodium channel in end-stage heart failure human heart. J. Mol. Cell Cardiol. 76, 126-129. doi: 10.1016/j.yjmcc.2014. 08.014

Benyair, R., Ron, E., and Lederkremer, G. Z. (2011). Protein quality control, retention, and degradation at the endoplasmic reticulum. Int. Rev. Cell Mol. Biol. 292, 197-280. doi: 10.1016/B978-0-12-386033-0.00005-0

Boehmer, C., Wilhelm, V., Palmada, M., Wallisch, S., Henke, G., Brinkmeier, H., et al. (2003). Serum and glucocorticoid inducible kinases in the regulation of the cardiac sodium channel SCN5A. Cardiovasc. Res. 57, 1079-1084. doi: 10.1016/s0008-6363(02)00837-4

Brewer, A., and Pizzey, J. (2006). GATA factors in vertebrate heart development and disease. Exp. Rev. Mol. Med. 8, 1-20. doi: 10.1017/S1462399406000093

Bruce, A. F., Rothery, S., Dupont, E., and Severs, N. J. (2008). Gap junction remodelling in human heart failure is associated with increased interaction of connexin43 with ZO-1. Cardiovasc. Res. 77, 757-765. doi: 10.1093/cvr/ cvm083

Cai, B., Wang, N., Mao, W., You, T., Lu, Y., Li, X., et al. (2014). Deletion of FoxO1 leads to shortening of QRS by increasing $\mathrm{Na}+$ channel activity through enhanced expression of both cardiac Nav1.5 and $\beta 3$ subunit. J. Mol. Cell Cardiol. 74, 297-306. doi: 10.1016/j.yjmcc.2014.06.006

Carnes, J., Jacobson, M., Leinwand, L., and Yarus, M. (2003). Stop codon suppression via inhibition of eRF1 expression. RNA 9, 648-653. doi: 10.1261/ rna.5280103

Chadda, K. R., Jeevaratnam, K., Lei, M., and Huang, C. L. (2017). Sodium channel biophysics, late sodium current and genetic arrhythmic syndromes. Pflug. Arch. 469, 629-641. doi: 10.1007/s00424-017-1959-1

Chakrabarti, S., Wu, X., Yang, Z., Wu, L., Yong, S. L., Zhang, C., et al. (2013). MOG1 rescues defective trafficking of $\mathrm{Na}_{\mathrm{V}} 1.5$ mutations in Brugada syndrome and sick sinus syndrome. Circ. Arrhythm Electrophysiol. 6, 392-401. doi: 10. 1161/CIRCEP.111.000206

Cheng, J., Valdivia, C. R., Vaidyanathan, R., Balijepalli, R. C., Ackerman, M. J., and Makielski, J. C. (2013). Caveolin-3 suppresses late sodium current by inhibiting
nNOS-dependent S-nitrosylation of SCN5A. J. Mol. Cell Cardiol. 61, 102-110. doi: 10.1016/j.yjmcc.2013.03.013

Chorin, E., Hu, D., Antzelevitch, C., Hochstadt, A., Belardinelli, L., Zeltser, D., et al. (2016). Ranolazine for congenital Long-QT Syndrome Type III: experimental and long-term clinical data. Circ. Arrhythm Electrophysiol. 9:e004370. doi: 10. 1161/CIRCEP.116.004370

Clark, K. A., McElhinny, A. S., Beckerle, M. C., and Gregorio, C. C. (2002). Striated muscle cytoarchitecture: an intricate web of form and function. Annu. Rev. Cell Dev. Biol. 18, 637-706. doi: 10.1146/annurev.cellbio.18.012502. 105840

Clatot, J., Hoshi, M., Wan, X. P., Liu, H. Y., Jain, A., Shinlapawittayatorn, K., et al. (2017). Voltage-gated sodium channels assemble and gate as dimers. Nat. Commun. 8:2077. doi: 10.1038/s41467-017-02262-0

Detta, N., Frisso, G., and Salvatore, F. (2015). The multi-faceted aspects of the complex cardiac $\mathrm{Na}_{\mathrm{V}} 1.5$ protein in membrane function and pathophysiology. Biochim. Biophys. Acta 1854, 1502-1509. doi: 10.1016/j.bbapap.2015.07.009

Ednie, A. R., Horton, K. K., Wu, J., and Bennett, E. S. (2013). Expression of the sialyltransferase, ST3Gal4, impacts cardiac voltage-gated sodium channel activity, refractory period and ventricular conduction. J. Mol. Cell Cardiol. 59, 117-127. doi: 10.1016/j.yjmcc.2013.02.013

Eichel, C. A., Beuriot, A., Chevalier, M. Y. E., Rougier, J.-S., Louault, F., Dilanian, G., et al. (2016). Lateral membrane-specific MAGUK CASK down-regulates Nav 1.5 channel in cardiac myocytes. Circ. Res. 119, 544-556. doi: 10.1161/ CIRCRESAHA.116.309254

Fahmi, A. I., Patel, M., Stevens, E. B., Fowden, A. L., John, I. I. I. J. E., Lee, K., et al. (2001). The sodium channel b-subunit SCN3b modulates the kinetics of SCN5A and is expressed heterogeneously in sheep heart. J. Physiol. 537, 693-700. doi: 10.1111/j.1469-7793.2001.00693.x

Gaborit, N., Sakuma, R., Wylie, J. N., Kim, K. H., Zhang, S. S., Hui, C. C., et al. (2012). Cooperative and antagonistic roles for Irx 3 and Irx 5 in cardiac morphogenesis and postnatal physiology. Development 139, 4007-4019. doi: 10.1242/dev.081703

Gaetano, C., Walzik, S., Schroeter, A., Benndorf, K., and Zimmer, T. (2011). Alternative splicing of the cardiac sodium channel creates multiple variants of mutant T1620K channels. PLoS One 6:e019188. doi: 10.1371/journal.pone. 0019188

Gao, C., Cai, Y., Wang, Y., Kang, B. H., Aniento, F., Robinson, D. G., et al. (2014). Retention mechanisms for ER and Golgi membrane proteins. Trends Plant Sci. 19, 508-515. doi: 10.1016/j.tplants.2014.04.004

Gao, G., and Dudley, S. C. Jr. (2013). SCN5A splicing variants and the possibility of predicting heart failure-associated arrhythmia. Exp. Rev. Cardiovasc. Ther. 11, 117-119. doi: 10.1586/erc. 12.180

Gao, G., Xie, A., Huang, S. C., Zhou, A., Zhang, J., Herman, A. M., et al. (2011). Role of RBM25/LUC7L3 in abnormal cardiac sodium channel splicing regulation in human heart failure. Circulation 124, 1124-1131. doi: 10.1161/ CIRCULATIONAHA.111.044495

Gao, G., Xie, A., Zhang, J., Herman, A. M., Jeong, E. M., Gu, L., et al. (2013). Unfolded protein response regulates cardiac sodium current in systolic human heart failure. Circ. Arrhythm Electrophysiol. 6, 1018-1024. doi: 10.1161/ CIRCEP.113.000274

Gavillet, B., Rougier, J. S., Domenighetti, A. A., Behar, R., Boixel, C., Ruchat, P., et al. (2006). Cardiac sodium channel $\mathrm{Na}_{\mathrm{V}} 1.5$ is regulated by a multiprotein complex composed of syntrophins and dystrophin. Circ. Res. 99, 407-414. doi: 10.1161/01.RES.0000237466.13252.5e

Ge, J., Sun, A., Paajanen, V., Wang, S., Su, C., Yang, Z., et al. (2008). Molecular and clinical characterization of a novel SCN5A mutation associated with atrioventricular block and dilated cardiomyopathy. Circ. Arrhythm. Electrophysiol. 1, 83-92. doi: 10.1161/CIRCEP.107.750752

Guan, Y., Gao, X., Tang, Q., Huang, L., Gao, S., Yu, S., et al. (2019). Nucleoporin 107 facilitates the nuclear export ofSCN5A mRNA to regulate cardiac bioelectricity. J. Cell Mol. Med. 23, 1448-1457. doi: 10.1111/jcmm. 14051

Han, D., Tan, H., Sun, C., and Li, G. (2018). Dysfunctional Nav1.5 channels due to SCN5A mutations. Exp. Biol. Med. 243, 852-863. doi: 10.1177/ 1535370218777972

Hesse, M., Kondo, C. S., Clark, R. B., Su, L., Allen, F. L., Geary-Joo, C. T. M., et al. (2007). Dilated cardiomyopathy is associated with reduced expression of the cardiac sodium channel SCN5A. Cardiovasc. Res. 75, 498-509. doi: 10.1016/j. cardiores.2007.04.009 
Huang, H., Priori, S. G., Napolitano, C., O’Leary, M. E., and Chahine, M. (2011). Y1767C, a novel SCN5A mutation, induces a persistent $\mathrm{Na}+$ current and potentiates ranolazine inhibition of $\mathrm{Na}_{\mathrm{V}} 1.5$ channels. Am. J. Physiol. Heart Circ. Physiol. 300, H288-H299. doi: 10.1152/ajpheart.00539.2010

Huang, Y., Wang, Z., Liu, Y., Xiong, H., Zhao, Y., Wu, L., et al. (2016). $\alpha \mathrm{B}$-Crystallin interacts with $\mathrm{Na}_{\mathrm{V}} 1.5$ and regulates ubiquitination and internalization of cell surface Nav1.5. J. Biol. Chem. 291, 11030-11041. doi: 10.1074/jbc.M115.695080

Ivan, P. G. M., Pizard, A., Patel, V. V., Bruneau, B. G., Kim, J. B., Kupershmidt, S., et al. (2004). The T-Box transcription factor Tbx 5 is required for the patterning and maturation of the murine cardiac conduction system. Development 131, 4107-4116. doi: 10.1242/dev.01265

Jiang, D., Shi, H., Tonggu, L., Gamal El-Din, T. M., Lenaeus, M. J., Zhao, Y., et al. (2020). Structure of the cardiac sodium channel. Cell 180, 122-134. doi: 10.1016/j.cell.2019.11.041

Johnson, D., and Bennett, E. S. (2006). Isoform-specific effects of the beta2 subunit on voltage-gated sodium channel gating. J. Biol. Chem. 281, 25875-25881. doi: 10.1074/jbc.M605060200

Ko, S. H., Lenkowski, P. W., Lee, H. C., Mounsey, J. P., and Patel, M. K. (2005). Modulation of $\mathrm{Na}(\mathrm{v}) 1.5$ by beta1- and beta3-subunit co-expression in mammalian cells. Pflug. Arch. 449, 403-412. doi: 10.1007/s00424-0041348-4

Koizumi, A., Sasano, T., Kimura, W., Miyamoto, Y., Aiba, T., Ishikawa, T., et al. (2016). Genetic defects in a His-Purkinje system transcription factor. IRX3, cause lethal cardiac arrhythmias. Eur. Heart J. 37, 1469-1475. doi: 10.1093/ eurheartj/ehv449

Kurokawa, K., and Nakano, A. (2019). The ER exit sites are specialized ER zones for the transport of cargo proteins from the ER to the Golgi apparatus. J. Biochem. 165, 109-114. doi: 10.1093/jb/mvy080

Lamothe, S. M., and Zhang, S. (2016). Chapter Five - Ubiquitination of ion channels and transporters. Prog. Mol. Biol. Transl. Sci. 141, 161-223. doi: 10. 1016/bs.pmbts.2016.02.005

Li, G., and Marlin, M. C. (2018). Rab Family of GTPases. Methods Mol. Biol. 1298, 1-15. doi: 10.1007/978-1-4939-2569-8_1

Li, W., Yin, L., Shen, C., Hu, K., Ge, J., and Sun, A. (2018). SCN5A variants: association with cardiac disorders. Front. Physiol. 9:1372. doi: 10.3389/fphys. 2018.01372

Li, X., Ortega, B., Kim, B., and Welling, P. A. (2016). A common signal patch drives AP-1 Protein-dependent Golgi export of inwardly rectifying potassium channels. J. Biol. Chem. 291, 14963-14972. doi: 10.1074/jbc.M116.729822

Liu, C.-J., Dib-Hajj, S. D., Renganathan, M., Cummins, T. R., and Waxman, S. G. (2003). Modulation of the cardiac sodium channel $\mathrm{Na}_{V} 1.5$ by fibroblast growth factor homologous factor 1B. J. Biol. Chem. 278, 1029-1036. doi: 10.1074/jbc. M207074200

Liu, X. H., Chen, Z., Han, Z. L., Liu, Y., Wu, X., Peng, Y. Z., et al. (2019). AMPKmediated degradation of Nav 1.5 through autophagy. FASEB J. 33, 5366-5376. doi: 10.1096/fj.201801583RR

Luo, L., Ning, F., Du, Y., Song, B., Yang, D., Salvage, S. C., et al. (2017). Calciumdependent Nedd4-2 upregulation mediates degradation of the cardiac sodium channel $\mathrm{Na}_{V}$ 1.5: implications for heart failure. Acta Physiol. 221, 44-58. doi: 10.1111/apha.12872

Makara, M. A., Curran, J., Little, S. C., Musa, H., Polina, I., Smith, S. A., et al. (2014). Ankyrin-G coordinates intercalated disc signaling platform to regulate cardiac excitability in vivo. Circ. Res. 115, 929-938. doi: 10.1161/CIRCRESAHA.115. 305154

Makielski, J. C. (2016). Late sodium current: a mechanism for angina, heart failure, and arrhythmia. Trends Cardiovasc. Med. 26, 115-122. doi: 10.1016/j.tcm.2015. 05.006

Mao, W., You, T., Ye, B., Li, X., Dong, H. H., Hill, J. A., et al. (2012). Reactive oxygen species suppress cardiac $\mathrm{Na}_{\mathrm{V}} 1.5$ expression through Foxo1. PLoS One 7:e32738. doi: 10.1371/journal.pone.0032738

Marangoni, S., Di Resta, C., Rocchetti, M., Barile, L., Rizzetto, R., Summa, A., et al. (2011). A Brugada syndrome mutation (p.S216L) and its modulation by p.H558R polymorphism: standard and dynamic characterization. Cardiovasc. Res. 91, 606-616. doi: 10.1093/cvr/cvr142

Marionneau, C., and Abriel, H. (2015). Regulation of the cardiac Na+ channel $\mathrm{Na}_{\mathrm{V}} 1.5$ by post-translational modifications. J. Mol. Cell Cardiol. 82, 36-47. doi: 10.1016/j.yjmcc.2015.02.013
Matsumura, H., Nakano, Y., Ochi, H., Onohara, Y., Sairaku, A., Tokuyama, T., et al. (2017). H558R, a common SCN5A polymorphism, modifies the clinical phenotype of Brugada syndrome by modulating DNA methylation of SCN5A promoters. J Biomed. Sci. 24:91. doi: 10.1186/s12929-017-0397-x

Mazzanti, A., Maragna, R., Faragli, A., Monteforte, N., Bloise, R., Memmi, M., et al. (2016). Gene-Specific Therapy With Mexiletine Reduces Arrhythmic Events in Patients With Long QT Syndrome Type 3. J. Am. Coll. Cardiol. 67, 1053-1058. doi: 10.1016/j.jacc.2015.12.033106

Medeiros-Domingo, A., Kaku, T., Tester, D. J., Iturralde-Torres, P., Itty, A., Ye, B., et al. (2007). SCN4B-encoded sodium channel beta4 subunit in congenital longQT syndrome. Circulation 116, 134-142. doi: 10.1161/CIRCULATIONAHA. 106.659086

Mercier, A. L., Clément, R., Harnois, T., Bourmeyster, N., Bois, P., and Chatelier, A. (2015). Na 1.5 channels can reach the plasma membrane through distinct N-glycosylation states. BBA Gen Subj. 1850, 1215-1223.

Mikosch, M., and Homann, U. (2009). How do ER export motifs work on ion channel trafficking? Curr. Opin. Plant Biol. 12, 685-689. doi: 10.1016/j.pbi.2009. 09.020

Moss, A. J., Zareba, W., Schwarz, K. Q., Rosero, S., McNitt, S., and Robinson, J. L. (2008). Ranolazine shortens repolarization in patients with sustained inward sodium current due to type-3 long-QT syndrome. J. Cardiovasc. Electrophysiol. 19, 1289-1293. doi: 10.1111/j.1540-8167.2008.01246.x

Munshi, N. V., McAnally, J., Bezprozvannaya, S., Berry, J. M., Richardson, J. A., Hill, J. A., et al. (2009). Cx30.2 enhancer analysis identifies Gata4 as a novel regulator of atrioventricular delay. Development 136, 2665-2674. doi: 10.1242/ dev.038562

Nieto, M. A. (2002). The snail superfamily of zinc-finger transcription factors. Nat. Rev. Mol. Cell Biol. 3, 155-166. doi: 10.1038/nrm757

Noyes, A. M., Zhou, A., Gao, G., Gu, L., Day, S., Andrew Wasserstrom, J., et al. (2017). Abnormal sodium channel mRNA splicing in hypertrophic cardiomyopathy. Int. J. Cardiol. 249, 282-286. doi: 10.1016/j.ijcard.2017.08.071

Nunez, L., Barana, A., Amoros, I., de la Fuente, M. G., Dolz-Gaiton, P., Gomez, R., et al. (2013). p.D1690N Nav 1.5 rescues p.G1748D mutation gating defects in a compound heterozygous Brugada syndrome patient. Heart Rhythm 10, 264-272. doi: 10.1016/j.hrthm.2012.10.025

Petitprez, S., Zmoos, A. F., Ogrodnik, J., Balse, E., Raad, N., El-Haou, S., et al. (2011). SAP97 and dystrophin macromolecular complexes determine two pools of cardiac sodium channels $\mathrm{Na}_{\mathrm{V}} 1.5$ in cardiomyocytes. Circ. Res. 108, 294-304. doi: 10.1161/CIRCRESAHA.110.228312

Plant, L. D., Xiong, D., Romero, J., Dai, H., and Goldstein, S. A. N. (2020). Hypoxia produces pro-arrhythmic late sodium current in cardiac myocytes by SUMOylation of Nav1.5 Channels. Cell Rep. 30, 2225-2236. doi: 10.1016/ j.celrep.2020.01.025

Rajamani, S., El-Bizri, N., Shryock, J. C., Makielski, J. C., and Belardinelli, L. (2009). Use-dependent block of cardiac late $\mathrm{Na}(+)$ current by ranolazine. Heart Rhythm 6, 1625-1631. doi: 10.1016/j.hrthm.2009.07.042

Rizzo, S., Lodder, E. M., Verkerk, A. O., Wolswinkel, R., Beekman, L., Pilichou, K., et al. (2012). Intercalated disc abnormalities, reduced $\mathrm{Na}(+)$ current density, and conduction slowing in desmoglein-2 mutant mice prior to cardiomyopathic changes. Cardiovasc. Res. 95, 409-418. doi: 10.1093/cvr/cvs219

Rook, M. B., Evers, M. M., Vos, M. A., and Bierhuizen, M. F. (2012). Biology of cardiac sodium channel $\mathrm{Na}_{\mathrm{V}} 1.5$ expression. Cardiovasc. Res. 93, 12-23. doi: $10.1093 / \mathrm{cvr} / \mathrm{cvr} 252$

Salvage, S. C., Huang, C. L., and Jackson, A. P. (2020). Cell-adhesion properties of beta-subunits in the regulation of cardiomyocyte sodium channels. Biomolecules 10:989. doi: 10.3390/biom10070989

Sato, P. Y., Musa, H., Coombs, W., Guerrero-Serna, G., Patino, G. A., Taffet, S. M., et al. (2009). Loss of plakophilin-2 expression leads to decreased sodium current and slower conduction velocity in cultured cardiac myocytes. Circ. Res. 105, 523-526. doi: 10.1161/CIRCRESAHA.109.201418

Schilling, J. M., Horikawa, Y. T., Zemljic-Harpf, A. E., Vincent, K. P., Tyan, L., Yu, J. K., et al. (2016). Electrophysiology and metabolism of caveolin3-overexpressing mice. Basic Res. Cardiol. 111:28. doi: 10.1007/s00395-0160542-9

Schluterman, M. K., Butler, C. A., Cohen, J. C., King, I. N., Srivastava, D., Eapen, R. S., et al. (2003). GATA4 mutations cause human congenital heart defects and reveal an interaction with TBX5. Nature 424, 443-447. doi: 10.1038/ nature 01827 
Schroeter, A., Walzik, S., Blechschmidt, S., Haufe, V., Benndorf, K., and Zimmer, T. (2010). Structure and function of splice variants of the cardiac voltage-gated sodium channel Na(v)1.5. J. Mol. Cell Cardiol. 49, 16-24. doi: 10.1016/j.yjmcc. 2010.04.004

Shang, L. L., and Dudley, S. C. (2005). Tandem promoters and developmentally regulated 5'- and 3'-mRNA untranslated regions of the mouse SCN5A cardiac sodium channel. J. Biol. Chem. 280, 933-940. doi: 10.1074/jbc.M40997 7200

Shang, L. L., Sanyal, S., Pfahnl, A. E., Jiao, Z., Allen, J., Liu, H., et al. (2008). NF-кBdependent transcriptional regulation of the cardiac SCN5A sodium channel by angiotensin II. Am. J. Physiol. Cell Ph 294, 372-379. doi: 10.1152/ajpcell.00186. 2007

Shinlapawittayatorn, K., Dudash, L. A., Du, X. X., Heller, L., Poelzing, S., Ficker, E., et al. (2011). A novel strategy using cardiac sodium channel polymorphic fragments to rescue trafficking-deficient SCN5A mutations. Circ. Cardiovasc. Genet. 4, 500-509. doi: 10.1161/CIRCGENETICS.111.960633

Sottas, V., Wahl, C. M., Trache, M. C., Bartolf-Kopp, M., Cambridge, S., Hecker, M., et al. (2018). Improving electrical properties of iPSC-cardiomyocytes by enhancing Cx43 expression. J. Mol. Cell Cardiol. 120, 31-41. doi: 10.1016/j. yjmcc.2018.05.010

Steggerda, S. M., and Paschal, B. M. (2001). Identification of a conserved loop in mog1 that releases GTP from Ran. Traffic 211, 804-811. doi: 10.1034/j.16000854.2001.21109.x

Steimle, J. D., and Moskowitz, I. P. (2017). TBX5: a key regulator of heart development. Curr. Top. Dev. Biol. 122, 195-221. doi: 10.1016/bs.ctdb.2016. 08.008

Tan, B. H., Pundi, K. N., Van Norstrand, D. W., Valdivia, C. R., Tester, D. J., Medeiros-Domingo, A., et al. (2010). Sudden infant death syndrome-associated mutations in the sodium channel beta subunits. Heart Rhythm 7, 771-778. doi: 10.1016/j.hrthm.2010.01.032

Tang, B., Hu, Y., Wang, Z., Cheng, C., Wang, P., Liang, L., et al. (2019). UBC9 regulates cardiac sodium channel $\mathrm{Na}_{\mathrm{V}} 1.5$ ubiquitination, degradation and sodium current density. J. Mol. Cell Cardiol. 129, 79-91. doi: 10.1016/j.yjmcc. 2019.02.007

Tarradas, A., Pinsach-Abuin, M. L., Mackintosh, C., Llora-Batlle, O., Perez-Serra, A., Batlle, M., et al. (2017). Transcriptional regulation of the sodium channel gene (SCN5A) by GATA4 in human heart. J. Mol. Cell Cardiol. 102, 74-82. doi: 10.1016/j.yjmcc.2016.10.013

Teng, S., Gao, L., Paajanen, V., Pu, J., and Fan, Z. (2009). Readthrough of nonsense mutation W822X in the SCN5A gene can effectively restore expression of cardiac Na+ channels. Cardiovasc. Res. 83, 473-480. doi: 10.1093/cvr/cvp116

Vaidyanathan, R., Reilly, L., and Eckhardt, L. L. (2018). Caveolin-3 microdomain: arrhythmia implications for potassium inward rectifier and cardiac sodium channel. Front. Physiol. 9:1548. doi: 10.3389/fphys.2018.01548

van Bemmelen, M. X., Rougier, J.-S., Gavillet, B., Apothéloz, F., Daidié, D., Tateyama, M., et al. (2004). Cardiac voltage-gated sodium channel Nav 1.5 is regulated by Nedd4-2 mediated ubiquitination. Circ. Res. 95, 284-291. doi: 10.1161/01.RES.0000136816.05109.89

Wagner, S., Dybkova, N., Rasenack, E. C. L., Jacobshagen, C., Fabritz, L., Kirchhof, P., et al. (2006). Ca2+/calmodulin-dependent protein kinase II regulates cardiac $\mathrm{Na}+$ channels. J. Clin. Invest. 116, 3127-3138. doi: 10.1172/Jci26620

Wang, C., Hennessey, J. A., Kirkton, R. D., Wang, C., Graham, V., Puranam, R. S., et al. (2011). Fibroblast growth factor homologous factor 13 regulates $\mathrm{Na}+$ channels and conduction velocity in murine hearts. Circ. Res. 109, 775-782. doi: 10.1161/CIRCRESAHA.111.247957

Wang, Q., Li, Z., Shen, J., and Keating, M. T. (1996). Genomic organization of the human SCN5A gene encoding the cardiac sodium channel. Genomics 34, 9-16. doi: 10.1006/geno.1996.0236

Wang, Z., Yu, G., Liu, Y., Liu, S., Aridor, M., Huang, Y., et al. (2018). Small GTPases SAR1A and SAR1B regulate the trafficking of the cardiac sodium channel Nay 1.5. Biochim. Biophys. Acta Mol. Basis Dis. 1864, 3672-3684. doi: 10.1016/j.bbadis.2018.09.003

Watanabe, H., Darbar, D., Kaiser, D. W., Jiramongkolchai, K., Chopra, S., Donahue, B. S., et al. (2009). Mutations in sodium channel beta1- and beta2-subunits associated with atrial fibrillation. Circ. Arrhythm. Electrophysiol. 2, 268-275. doi: 10.1161/CIRCEP.108.779181

Yang, H.-Q., Pérez-Hernández, M., Sanchez-Alonso, J., Shevchuk, A., Gorelik, J., Rothenberg, E., et al. (2020). Ankyrin-G mediates targeting of both $\mathrm{Na}$ and $\mathrm{K}$ channels to the rat cardiac intercalated disc. eLife 9:e52373. doi: 10.7554/eLife. 52373

Yang, Q., Xiong, H., Xu, C., Huang, Y., Tu, X., Wu, G., et al. (2019). Identification of rare variants in cardiac sodium channel beta4-subunit gene SCN4B associated with ventricular tachycardia. Mol. Genet. Genom. 294, 1059-1071. doi: 10.1007/ s00438-019-01567-7

Yoon, J. Y., Vikram, A., London, B., and Irani, K. (2017). Reversible lysine acetylation: another layer of post-translational regulation of the cardiac sodium channel. Channels 11, 360-361. doi: 10.1080/19336950.2017.1340015

Yu, G., Liu, Y., Qin, J., Wang, Z., Hu, Y., Wang, F., et al. (2018). Mechanistic insights into the interaction of the MOG1 protein with the cardiac sodium channel Nav 1.5 clarify the molecular basis of Brugada syndrome. J. Biol. Chem. 293, 18207-18217. doi: 10.1074/jbc.RA118.003997

Zhang, D., Tang, Z., Huang, H., Zhou, G., Cui, C., Weng, Y., et al. (2019). Metabolic regulation of gene expression by histone lactylation. Nature 574, 575-580. doi: 10.1038/s41586-019-1678-1

Zhang, Q., Deng, C., Rao, F., Modi, R. M., Zhu, J., Liu, X., et al. (2013). Silencing of desmoplakin decreases connexin $43 / \mathrm{Na}_{\mathrm{V}} 1.5$ expression and sodium current in HL1 cardiomyocytes. Mol. Med. Rep. 8, 780-786. doi: 10.3892/mmr.2013.1594

Zhao, Y., Huang, Y., Li, W., Wang, Z., Zhan, S., Zhou, M., et al. (2015). Posttranscriptional regulation of cardiac sodium channel gene SCN5A expression and function by miR-192-5p. Biochim. Biophys. Acta 1852, 2024-2034. doi: 10.1016/j.bbadis.2015.07.016

Zhou, A., Shi, G., Kang, G. J., Xie, A., Liu, H., Jiang, N., et al. (2018a). RNA binding protein, HuR, regulates SCN5A expression through stabilizing MEF2C transcription factor mRNA. J. Am. Heart Assoc. 7:e007802. doi: 10.1161/JAHA. 117.007802

Zhou, A., Xie, A., Kim, T. Y., Liu, H., Shi, G., Kang, G.-J., et al. (2018b). HuRmediated SCN5A mRNA stability reduces arrhythmic risk in heart failure. Heart Rhythm 15, 1072-1080. doi: 10.1016/j.hrthm.2018.02.018

Zhou, J., Shin, H. G., Yi, J., Shen, W., Williams, C. P., and Murray, K. T. (2002). Phosphorylation and putative ER retention signals are required for protein kinase A-mediated potentiation of cardiac sodium current. Circ. Res. 91, 540-546. doi: 10.1161/01.res.0000033598.00903.27

Zhu, W., Mazzanti, A., Voelker, T. L., Hou, P., Moreno, J. D., Angsutararux, P., et al. (2019). Predicting patient response to the antiarrhythmic mexiletine based on genetic variation. Circ. Res. 124, 539-552. doi: 10.1161/CIRCRESAHA.118. 314050

Zhu, W., Voelker, T. L., Varga, Z., Schubert, A. R., Nerbonne, J. M., and Silva, J. R. (2017). Mechanisms of noncovalent beta subunit regulation of $\mathrm{NaV}$ channel gating. J. Gen. Physiol. 149, 813-831. doi: 10.1085/jgp.201711802

Conflict of Interest: The authors declare that the research was conducted in the absence of any commercial or financial relationships that could be construed as a potential conflict of interest.

Copyright (c) 2020 Dong, Wang, Ma and Wang. This is an open-access article distributed under the terms of the Creative Commons Attribution License (CC BY). The use, distribution or reproduction in other forums is permitted, provided the original author(s) and the copyright owner(s) are credited and that the original publication in this journal is cited, in accordance with accepted academic practice. No use, distribution or reproduction is permitted which does not comply with these terms. 